GRASAS Y ACEITES 67 (4)

October-December 2016, e169

ISSN-L: 0017-3495

doi: http://dx.doi.org/10.3989/gya.0457161

\title{
Markers of quality and genuineness of commercial extra virgin sacha inchi oils
}

\author{
N.A. Chasquibol ${ }^{\mathrm{a}}$, R.B. Gómez-Coca ${ }^{\mathrm{b}}$, J.C. Yácono $^{\mathrm{a}}$, Á. Guinda ${ }^{\mathrm{b}}$, W. Moreda ${ }^{\mathrm{b}}$, \\ C. del Aguila ${ }^{b}$ and M.C. Pérez-Camino ${ }^{b, \bowtie}$ \\ ${ }^{a}$ Faculty of Industrial Engineering, Institute of Scientific Research, (IDIC), Universidad de Lima, Avenida Javier \\ Prado Este $\mathrm{N}^{\circ} 4600$, Urb. Fundo Monterrico Chico, Santiago de Surco, Lima, Peru. \\ ${ }^{b}$ Department of Characterization and Quality of Lipids, Instituto de la Grasa, CSIC, Campus Pablo de \\ Olavide University, Bdg. 46, 41013 Sevilla, Spain. \\ ${ }^{\square}$ Corresponding author: mcperezcamino@ig.csic.es
}

Submitted: 26 April 2016; Accepted: 19 September 2016

SUMMARY: This work tackles the study of the quality and authenticity of oils labeled and commercialized as extra virgin sacha inchi oil. Major and minor components as triglycerides, fatty acid methyl esters, tocopherols, sterols and hydrocarbons are determined as well as other physicochemical parameters (density, viscosity, acidity and peroxide value). The results showed that some of the commercialized oils do not fulfill the basic requirement established in the regulation such as the content of $\alpha$-linolenic acid, higher than 44.7 or $55.0 \%$ in the cases of P. volubilis and $P$. huayllabambana, respectively. The calculated stigmasterol/campesterol ratio for genuine sacha inchi oils should be around 4, however not all commercial oils analyzed comply with this requirement. The presence of the flavons sesamin and sesamolin indicates the addition of compounds from sesame oils. Finally, some of the commercial oils showed to contain trans fatty acids although this was not accompanied by the sterene hydrocarbon presence.

KEYWORDS: Authenticity; Characterization; Commercial sacha inchi oils; Purity; Quality parameters

RESUMEN: Marcadores de la calidad y la genuinidad de aceites de sacha inchi extra virgen comerciales. En este trabajo se aborda el estudio de la calidad y la genuinidad de los aceites etiquetados y comercializados como sacha inchi extra virgen. Se estudian los componentes mayoritarios como los triglicéridos y los ésteres metílicos de ácidos grasos, componentes menores insaponificables (tocoferoles, esteroles e hidrocarburos) así como otros parámetros fisicoquímicos (densidad, viscosidad, acidez, peróxidos y estabilidad). Los resultados mostraron que algunos de los aceites comercializados no cumplían con el requisito básico establecido en la normativa de tener un contenido en $\alpha$-linolénico superior a 44,7 o $55,0 \%$ determinado para $P$. volubilis o $P$. huayllabambana respectivamente. La relación estigmasterol/campesterol medida en aceites de sacha inchi genuinos es de alrededor de 4, y no todos los aceites comerciales analizados cumplían con este requisito. La presencia de las flavonas sesamina y sesamolina indica la adición de compuestos procedentes de aceites de sésamo. Por último, algunos de los aceites comerciales estudiados, contenían ácidos grasos trans aunque no se detectó en ellos la presencia de hidrocarburos esteroideos.

PALABRAS CLAVE: Aceites de sacha inchi comerciales; Autenticidad; Caracterización; Parámetros de calidad; Pureza

Citation/Cómo citar este artículo: Chasquibol NA, Gómez-Coca RB, Yácono JC, Guinda Á, Moreda W, del Aguila C, Pérez-Camino MC. 2016. Markers of quality and genuineness of commercial extra virgin sacha inchi oils. Grasas Aceites 67, e169. http://dx.doi.org/10.3989/gya.0457161.

Copyright: (C) 2016 CSIC. This is an open-access article distributed under the terms of the Creative Commons Attribution (CC-by) Spain 3.0 License. 


\section{INTRODUCTION}

Sacha inchi oil is a singular, although globally is an almost unknown, edible oil which belongs to the Plukenetia gender and is native to the Peruvian Amazon. One of its most relevant peculiarities is to be one of the edible oils with the highest content of $\omega 3$ fatty acids $(44.7-55.0 \% \alpha$-linolenic acid (Ln), depending on the ecotype) (Gutiérrez et al., 2011; Maurer et al., 2012; NTP, 2010; NTP 2014; Liua et al., 2014), along with a particular sterol composition (stigmasterol>campesterol), and high amounts of $\gamma$ and $\delta$-tocopherols $\left(>1900 \mathrm{mg} \cdot \mathrm{kg}^{-1}\right)$. Sacha inchi oils are consumed as virgin oils since they have a highly appreciated 'flowered' taste. All those particularites justify the development of research studies on their nutritional and health benefits (Muñoz Jauregui et al., 2013). Besides, in 2014 the Food and Drugs Administration (FDA) declared sacha inchi oils as safe food (GRAS). Thanks to all those facts there are presently 11 companies which export sacha inchi oil from Peru to US, which suppose $9 \%$ of their exportations. The most important part of the Peruvian exportations $(40 \%)$ goes to the Netherlands. Also in 2014 four Peruvian companies got the inclusion of sacha inchi oil into the European market by getting its exclusion from the Novel Food list. The category of Novel Food prevents the entry of foods which do not had a significant history of consumption in the European Union before May 1997 into the European market. After the Netherlands, Spain is the main importing country of sacha inchi oils (32\%).

Although there are 16 species of the genus Plukenetia described (Bussmann et al., 2009), six of them growing in the Peruviam Amazon (Rodriguez et al., 2010), at present commercial sacha inchi oils come almost exclusively from the $P$. volubilis ecotype. The oils are obtained through artisanal production with a cold-press solvent-free system, and the use of decanters and filters in order to eliminate suspended particles and water. Before extraction, sacha inchi seeds are partially peeled and cleaned by ventilation to remove impurities, they are then milled mechanically. The oils obtained must comply with the requirements established in the regulations (NTP, 2010; NTP 2014). The specifications of quality and safety are established for all oils of the Plukenetia gender, although some parameters are specific for $P$. volubilis and $P$. huayllabambana oils. Due to their positive properties and also because of their time-consuming preparation, sacha inchi oils are very expensive. Hence and, taking advantage of the laxity of its regulation, fraudulent practices can be easily undertaken.

After a complete characterization of two of the most popular varieties of sacha inchi oils, $P$. volubilis and P. huayllabambana (Chasquibol et al., 2012, Chasquibol et al., 2014) we are in position to study the quality and genuineness of the commercialized sacha inchi oils.

\section{MATERIALS AND METHODS}

\subsection{Oil samples}

Fourteen (C-1 to C-14) sacha inchi oil samples, labeled as extra virgin from different commercial branches, were purchased in specialized shops of Lima (Perú) during 2012-2015. Samples, showed as expiration date 2014-2016 and were stored in freezer until analysis. They were bottled in dark-green 250 $\mathrm{mL}$ glass bottles, except in the case of C-8 sample that came in a brown $125 \mathrm{~mL}$ glass container. In all cases, it was specified that the oils contained $48 \%$ $\oplus 3$-acid, and in most of the samples also a 36\% linoleic and 9\% oleic acid contents were pointed out. An acidity value below $1 \%$ was specified in C-2 and C-8 samples, and the fact of belonging to the volubilis ecotype was indicated in the labels of C-8, C-9 and $\mathrm{C}-12$ bottles. Special reference to the absence of trans fatty acids was made for C-6 and C-7 samples.

\subsection{Reagents and solutions}

Acetone, diethyl ether, and hexane were supplied by VWR International (West Chester, PA, USA). HPLC grade propionitrile was supplied by Panreac. Si-SPE cartridges were from Varian (EA Middelburg, The Netherlands). Standards of 5 - $\alpha$-cholestan- $3 \beta$-ol and trilinolenin ( $\mathrm{LnLnLn}$ ) were from Sigma-Adrich Co. (St. Louis, MO, USA). Hexamethyldisilazane, pyridine, trimethylchloroxilane, and standards of eicosane and tocopherols were from Merck-España (Merck Group, Darm- stadt, Germany).

\subsection{Physical-chemical parameters}

Physical indexes (iodine value, refractive index, density, and viscosity), physicochemical parameters (triacylgycerol, fatty acid methyl ester, tocopherol, sterol, and hydrocarbon contents), quality indexes (percentage of acidity and peroxide value), and stability parameters (Rancimat test) were determined in order to evaluate both, oil quality and authenticity.

Free fatty acid (FA) content and peroxide value were determined according to the AOCS Official Methods (AOCS, 2012, 2013).

The oxidative stability was determined following the standard Official Method Cd 12-b- 92,18,19 using a Rancimat equipment (743 Rancimat Metrohm Co., Basel, Switzerland), with an air flow of $20 \mathrm{~L} \cdot \mathrm{h}^{-1}$ at $100 \pm 1{ }^{\circ} \mathrm{C}$ (AOCS, 1997)

Viscosity and density were measured using a Stabinger SVM 3000 viscometer (Anton Paar $\mathrm{GmbH}$ Graz, Austria), and the refractive index was determined with a temperature-controlled Abbe refractometer (Hilger \& Watts Ltd., London, U.K.) (Ourrach et al., 2012)

The iodine value was determined according to UNE-EN 14111, 2003 where the unsaturated FA 
composition is taken into account according to the following formula:

$$
\begin{aligned}
& 0.95 \times \% \mathrm{C}_{16: 1}+0.8986 \times \% \mathrm{C}_{18: 1}+1.81 \times \% \mathrm{C}_{18: 2} \\
& \quad+2.735 \times \mathrm{C}_{18: 3}+0.8175 \times \mathrm{C}_{20: 1}+0.7497 \times \\
& \% \mathrm{C}_{22: 1}
\end{aligned}
$$

\subsection{Major glyceridic components}

We will include fatty acid methyl esters and triglyceride composition in this Section.

\subsubsection{Fatty acid composition}

The fatty acid composition was determined by gas chromatography (GC) as fatty acid methyl esters (FAME) according to the IUPAC Standard Method (IUPAC, 1987a). Oil samples (50 mg) were transesterified using $0.5 \mathrm{~mL} 2 \mathrm{~N}$ methanolic solution of potassium hydroxide. GC analysis was carried out using an HP 7890B gas chromatograph (HewlettPackard, Palo Alto, CA) equipped with a capillary column (poly (90\% biscyanopropyl-10\% cyanopropylphenyl) siloxane, $60 \mathrm{~m} \AA \sim 0.25 \mathrm{~mm}$ i.d.; $0.20 \mu \mathrm{m}$ film thickness) and a automatic split injector and a flame ionization detector (FID). The carrier gas was hydrogen at a flow rate of $1 \mathrm{~mL} \mathrm{~min}^{-1}$. The temperatures of the injector and detector were 225 and 250 ${ }^{\circ} \mathrm{C}$, respectively. The oven was programmed at a temperature of $165^{\circ} \mathrm{C}(10 \mathrm{~min})$, which was then increased by $1.5^{\circ} \mathrm{C} \mathrm{min}{ }^{-1}$ up to $200{ }^{\circ} \mathrm{C}(10 \mathrm{~min})$. The injection volume was $1 \mu \mathrm{L}$. The fatty acid composition was expressed as relative percentage of each fatty acid on total fatty acids.

\subsubsection{HPLC-RI Triglyceride analysis}

Triacylglycerols (TG) were separated by HPLC on a Lichrosphere 100 RP-18 $(4 \mu)$ column (Moreda et al., 2003). Previously, the oil samples were purified by silica-SPE. A solution of the oil $(0.10 \mathrm{~g}$ in $0.5 \mathrm{~mL}$ of hexane) was charged into the column and pulled with $10 \mathrm{~mL}$ of the hexane-diethyl ether $(87: 13 \mathrm{v} / \mathrm{v})$ admixture. The collected fraction was evaporated to dryness, and the residue dissolved in $2 \mathrm{~mL}$ acetone and injected $(10 \mu \mathrm{L})$ onto the HPLC system using a Beckman Gold 508 auto-sampler (Beckman-Coulter, Fullerton, CA, USA). The analyses were done using a Beckman Gold 126 pumping unit (Beckman-Coulter, Fullerton, CA, USA), a refractive index detector (RI) Perkin Elmer 200 (Perkin Elmer, Norwalk, CT, USA) and a Beckman Mistral peltier column thermostat unit fixed at $20^{\circ} \mathrm{C}$ (Beckman-Coulter, Fullerton, CA, USA). The elution was done with propionitrile at a flow rate of $0.6 \mathrm{~mL} \cdot \mathrm{min}^{-1}$. The $\mathrm{TG}$ composition was expressed as relative percentage of each group of TG with the same Equivalent Carbon Number (ECN) on total TG.

\subsection{Minor unsaponifiable compounds}

As minor unsaponifiable compounds we considered sterols, hydrocarbons and tocopherols (GómezCoca et al., 2015). Just for sterol determination it is necessary to get the unsaponifiable matter in order to isolate and determine them quantitatively.

\subsubsection{Sterol composition}

The sterol fraction was isolated from the unsaponifiable matter (IUPAC, 1987c) by preparative HPLC fitted with a Si-column $(250 \mathrm{~mm} \mathrm{\AA ⿻}$ $4 \mathrm{~mm}$ i.d.; $4 \mu \mathrm{m}$ particle size) (Cert et al., 1997). An hexane:diethyl ether $(1: 1, \mathrm{v} / \mathrm{v})$ solution at a flow rate of $0.8 \mathrm{~mL} \cdot \mathrm{min}^{-1}$ was used as eluent, together with UV detection at $210 \mathrm{~nm}$. The fraction of interest eluted at $\mathrm{Rt}=10-25 \mathrm{~min}$ and it contained both the sterols and the triterpenic dialcohols. The collected portion was evaporated until dryness, derivatized with $500 \mu \mathrm{L}$ of the 1:3:9 (v/v/v) trimethylchloroxil ane:hexamethyldisilazane: pyridine admixture and analyzed by GC. The gas chromatograph (Agilent $6890 \mathrm{~N}$ ) was equipped with a fused silica column (poly (5\% diphenyl- 95\% dimethyl) siloxane, $30 \mathrm{~m}$, Å $0.25 \mathrm{~mm}$ i.d., $\AA \sim 0.25 \mu \mathrm{m}$ film thickness), and FID. The oven was programmed isothermally at $260{ }^{\circ} \mathrm{C}$, and the split ratio was 1:50. Hydrogen was used as carrier gas at a flow rate of $1 \mathrm{~mL} \cdot \mathrm{min}^{-1}$. The injector and detector temperature was $300^{\circ} \mathrm{C}$. The quantitative determination was done starting from $5 \mathrm{~g}$ of the oil sample and using $\alpha$-cholestanol at a concentration of $1 \mathrm{mg} \cdot \mathrm{mL}^{-1}$ as internal standard.

\subsubsection{Tocopherols}

Tocopherols were determined according to the IUPAC Standard Method 2432 (IUPAC 1987b). The oil solution in hexane $\left(10 \mathrm{mg} \cdot \mathrm{mL}^{-1}\right)$ was analyzed by HPLC fitted with a silica-column (250 mm Å 4 mm i.d.; $4 \mu \mathrm{m}$ particle size). A solution of hexane:2-propanol $(99: 1, \mathrm{v} / \mathrm{v})$ at a flow rate of $1 \mathrm{~mL} \cdot \mathrm{min}^{-1}$ was used as a eluent and the detection was done by fluorescence (RF-10AXL Shimadzu fluorescence) at $\lambda=290$ and $330 \mathrm{~nm}$, (excitation and emission, respectively). Standards of tocopherols in hexane at concentrations of $4-6 \mu \mathrm{g} \cdot \mathrm{mL}^{-1}$ were used for quantitative determinations.

\subsubsection{Hydrocarbon fractions}

2.5.3.1. Aliphatic saturated hydrocarbon quantification. Aliphatic saturated hydrocarbons (HC) were determined following a procedure previously described with minor modifications (Moreda et al., 2001; Gómez-Coca et al., 2016). The fraction containing the $\mathrm{HC}$ was isolated by low-pressure column chromatography filled with $15 \mathrm{~g}$ of silica gel (Si-60) impregnated with $\mathrm{AgNO}_{3}$. A sample of 
$0.5 \mathrm{~g}$ oil introduced into the column was eluted with $80 \mathrm{~mL}$ petroleum ether, evaporated until dryness, re-dissolved in $0.5 \mathrm{~mL}$ hexane, and analyzed by oncolumn GC. The gas chromatogram was equipped with a poly-5\% diphenyl-95\% dimethylsiloxane, capillary column of $12 \mathrm{~m}, 0.32 \mathrm{~mm} \AA$ i.d., $0.1 \mu \mathrm{m}$ film thickness. The initial oven temperature was set at $80{ }^{\circ} \mathrm{C}$ for $2 \mathrm{~min}$, and the rate was established at $12^{\circ} \mathrm{C} \cdot \mathrm{min}^{-1}$ up to $280^{\circ} \mathrm{C}$, then at $7^{\circ} \mathrm{C} \cdot \mathrm{min}^{-1}$, and then up to $340^{\circ} \mathrm{C}$. The injector temperature was set at $80^{\circ} \mathrm{C}$ and the FID temperature at $350^{\circ} \mathrm{C}$. Eicosane $(\mathrm{C} 20: 0)$ at a concentration of $0.05 \mathrm{mg} \cdot \mathrm{mL}^{-1}$ was used as internal standard.

2.5.3.2. Steroideal hydrocarbons. Sterene determination was carried out according to the method developed by Cert et al., 1994, which was standardized by the IUPAC (Dobarganes et al., 1999) and included in International Regulations (ISO, 1999). The unsaponifiable matter was obtained from $20 \mathrm{~g}$ of each oil sample (IUPAC, 1987) and isolated by means of low-pressure column chromatography using light petroleum as eluent. After discarding a first fraction, a second one is collected and analyzed by GC on a fused-silica capillary column $(30 \mathrm{~m}$ x $0.25 \mathrm{~mm}$ i.d., $0.1 \mu \mathrm{m}$ film thickness) coated with 5\% diphenyl 95\%-methylpolysiloxane. The oven temperature program was: $235^{\circ} \mathrm{C}$ for $6 \mathrm{~min}$, and then to rise to $285^{\circ} \mathrm{C}$ at 2 ${ }^{\circ} \mathrm{C} \cdot \mathrm{min}^{-1}$. Hydrogen was used as carrier gas at a flow rate of $1 \mathrm{~mL} \cdot \mathrm{min}^{-1}$

\section{Statistical analysis}

Each analytical determination was done in triplicate and data were presented as their average and standard deviation.

\section{RESULTS AND DISCUSSION}

Sacha inchi from the $P$. volubilis and $P$. huayllabambana ecotypes are the most extended cultivars among their gender, although the first one is the most common for oil production and commercialization. The oils from all the plukenetia gender have to fulfill with the quality parameters specified in the Peruvian regulation (NTP, 2010), although specific parameters are established for the $P$. volubilis and $P$. huayllabambana ecotypes as far as the characterization parameters are concern, since it is known that both of them differ slightly in their composition.

\subsection{Analytical indexes and oxidative stability}

The majority of the values for the indexes commonly used to evaluate the initial quality of sacha inchi commercial oils, i.e., FA, and PV, were found within the expected ranges for oils of good quality (Table 1). All of the studied samples could be classified as extra virgin according to the acidity values included in the regulation with the exception of C-2, $\mathrm{C}-11, \mathrm{C}-12$ and $\mathrm{C}-13$ samples. According to this quality parameter the mentioned samples could be

TABLE 1. Physicochemical parameters of the sacha inchi commercial oils under study.

\begin{tabular}{|c|c|c|c|c|c|c|c|c|}
\hline & $\begin{array}{c}\text { Acidity } \\
(\%)\end{array}$ & $\begin{array}{c}\text { Peroxide } \\
\text { Value } \\
\left(\mathrm{meq}_{2} \mathrm{O}_{2} \cdot \mathrm{kg}^{-1} \text { oil) }\right.\end{array}$ & $\begin{array}{c}\text { Iodine } \\
\text { Index }^{\mathrm{a}} \\
\left(\mathrm{gI}_{2} \cdot \mathbf{1 0 0 g}^{-1}\right)\end{array}$ & $\begin{array}{l}\text { Refracctive } \\
\text { Index }\end{array}$ & $\begin{array}{c}\text { Densidity } \\
\left(\mathrm{g} \cdot \mathrm{cm}^{-3}\right)\end{array}$ & $\begin{array}{l}\text { Viscosity } \\
\text { (mPa.s) }\end{array}$ & $\begin{array}{l}\text { Rancimat } \\
\text { (h) }\end{array}$ & $\begin{array}{c}\text { Unsaponifiable } \\
\text { Matter (\%) }\end{array}$ \\
\hline $\mathrm{C}-1$ & $0.7 \pm 0.00$ & $4.84 \pm 0.06$ & $191.9 \pm 0.1$ & 1.4780 & $0.9265 \pm 0.0000$ & $52.3 \pm 0.26$ & $6.6 \pm 0.1$ & $1.03 \pm 0.12$ \\
\hline $\mathrm{C}-2$ & $2.0 \pm 0.05$ & $8.38 \pm 0.08$ & $196.4 \pm 0.2$ & 1.4790 & $0.9263 \pm 0.0000$ & $45.1 \pm 0.25$ & $3.4 \pm 0.1$ & $2.15 \pm 0.25$ \\
\hline $\mathrm{C}-3$ & $0.6 \pm 0.00$ & $15.37 \pm 0.06$ & $116.1 \pm 0.1$ & 1.4710 & $0.9156 \pm 0.0000$ & $65.3 \pm 0.48$ & $3.4 \pm 0.1$ & $1.52 \pm 0.02$ \\
\hline C-4 & $0.2 \pm 0.01$ & $6.37 \pm 0.04$ & $203.6 \pm 0.1$ & 1.4800 & $0.9264 \pm 0.0000$ & $47.2 \pm 0.80$ & $3.9 \pm 0.1$ & $2.58 \pm 0.30$ \\
\hline C-5 & $0.5 \pm 0.00$ & $8.87 \pm 0.12$ & $153.3 \pm 0.1$ & 1.4750 & $0.9265 \pm 0.0000$ & $55.9 \pm 0.41$ & $5.4 \pm 0.1$ & $1.62 \pm 0.09$ \\
\hline C-6 & $0.9 \pm 0.01$ & $3.86 \pm 0.09$ & $135.6 \pm 0.1$ & 1.4730 & $0.9270 \pm 0.0000$ & $55.7 \pm 0.68$ & $8.3 \pm 0.1$ & $2.33 \pm 0.76$ \\
\hline $\mathrm{C}-7$ & $0.4 \pm 0.01$ & $3.85 \pm 0.10$ & $147.4 \pm 0.7$ & 1.4750 & $0.9384 \pm 0.0000$ & $53.7 \pm 0.32$ & $10.3 \pm 0.1$ & $1.69 \pm 0.18$ \\
\hline $\mathrm{C}-8$ & $0.3 \pm 0.01$ & $7.26 \pm 0.02$ & $198.8 \pm 0.1$ & 1.4801 & $0.9293 \pm 0.0000$ & $50.7 \pm 0.45$ & $4.8 \pm 0.1$ & $1.44 \pm 0.13$ \\
\hline C-9 & $0.2 \pm 0.01$ & $6.39 \pm 0.01$ & $161.9 \pm 0.1$ & 1.4762 & $0.9199 \pm 0.0000$ & $46.8 \pm 0.25$ & $9.2 \pm 0.1$ & $1.48 \pm 0.05$ \\
\hline C-10 & $1.6 \pm 0.02$ & $7.2 \pm 0.01$ & $203.4 \pm 0.1$ & 1.4805 & $0.9291 \pm 0.0000$ & $49.6 \pm 0.34$ & $3.9 \pm 0.1$ & $1.05 \pm 0.20$ \\
\hline C-11 & $0.5 \pm 0.01$ & $7.6 \pm 0.01$ & $164.8 \pm 0.1$ & 1.4751 & $0.9241 \pm 0.0000$ & $58.5 \pm 0.38$ & $7.6 \pm 0.1$ & $1.85 \pm 0.15$ \\
\hline C-12 & $1.8 \pm 0.10$ & $4.00 \pm 0.01$ & $202.1 \pm 0.1$ & 1.4805 & $0.9288 \pm 0.0000$ & $50.1 \pm 0.45$ & $3.9 \pm 0.1$ & $1.05 \pm 0.10$ \\
\hline C-13 & $2.0 \pm 0.01$ & $7.15 \pm 0.01$ & $198.4 \pm 0.1$ & 1.4800 & $0.9289 \pm 0.0000$ & $48.8 \pm 0.35$ & $3.8 \pm 0.1$ & $0.82 \pm 0.06$ \\
\hline C-14 & $0.7 \pm 0.02$ & $9.70 \pm 0.01$ & $220.8 \pm 0.1$ & 1.4800 & $0.9289 \pm 0.0000$ & $47.8 \pm 0.27$ & $3.2 \pm 0.1$ & $1.00 \pm 0.19$ \\
\hline $\mathrm{NTP}^{\mathrm{c}}$ & $\begin{array}{l}<1 \% \\
<2 \%\end{array}$ & $<10$ & $183-199^{b}$ & $1.478-1.481$ & $0.926-0.931$ & & & $<0.36$ \\
\hline
\end{tabular}

${ }^{a}$ UNE-EN 14111:2003.

${ }^{\mathrm{b}} \mathrm{HANUS}$.

${ }^{c}$ Peruvian regulation. 
classified as virgin but not as extra virgin because sacha inchi regulation establishes maximum values of 1.0 and 2.0 (expressed as a percent of oleic acid) for extra and for virgin oils, respectively. One of the analyzed samples (C-3) exceed the maximum PV of 10 meq $\mathrm{O}_{2} \cdot \mathrm{kg}^{-1}$, what meant that this sample presented an oxidation level higher than that expected for good oils.

The iodine index is a determination directly related to the presence of double bonds in the FA of the oil. We determined it taking into account a response factor for each unsaturated FA according to the normative UNE.

The refractive index, density and viscosity, at $20{ }^{\circ} \mathrm{C}$ were in the ranges: $1.4701-1.4805,0.9156-$ $0.9384 \mathrm{~g} \cdot \mathrm{cm}^{-3}$, and $45.1-65.3 \mathrm{mPa} \cdot \mathrm{s}$, respectively. The C-3, C-7 and C-9 samples were out of the ranges established in the regulation for both, refractive index and density. The C-5, C-6, and C-11 samples complied with the density range but not with the refractive index.

In relation to the unsaponifiable matter, we believe that there must be an error since the current regulations restrict this parameter to $0.36 \%$ and important compounds such as sterols and tocopherols are included in this fraction and it has no sense to establish a limit. In fact, all the studied commercial oil samples have percentages of the unsaponifiable matter in the $1.00-2.69 \%$ range, higher than the current limit.

The oil stability measured as Rancimat hours at $100{ }^{\circ} \mathrm{C}$ were in the $3.2-10.3$ range. The values were closely related to the unsaturation of the oil sample and thus, the higher the iodine value the lower the Rancimat hours. The degree of oxidation also influences the lost of hours of stability, for that reason C-3 sample, with the lowest iodine value, would be expected to have the highest stability although it was not the case.

\subsection{Major components}

The oils from the P. volubilis ecotype must have at least $44.7 \% \alpha$-linolenic acid whereas oils from the $P$. huayllabambana should contain $55.5 \%$, according to the regulation. Our previous results, with authentic sacha inchi oils extracted by us through a mechanical process, utilizing seeds from both varieties complied with the regulation (Chasquibol et al., 2012; Chasquibol et al., 2014). Therefore, we are in position of expecting at least $44.7 \%$ linolenic, 32.1$24.9 \%$ linoleic, and $8.9-7.9 \%$ oleic acid contents in the authentic sacha inchi oils, assuming that the ecotypes are actually $P$. volubilis or P. huayllabambana. Nevertheless, as we can see in Table 2, C-3, C-5, C-6, C-7, C9, and C-11 samples do not satisfy this requirement. Besides, four of the above mentioned samples (C-3, C-5, C-6 and C-11) contain trans-FA that, although is a parameter not included in the current regulation, is determined at the same time than the cis-FA. Actually, one of the commercial samples specified on its label the absence of trans-fat since these are indicative of a heated or a bleaching process, both normal steps of the refining procedure.

In the oil extraction process from seeds, a previous step consisting of subjecting the seed to roasting by applying high temperatures $\left(<180^{\circ} \mathrm{C}\right)$ is usual. The purpose of this step is to eliminate humidity, and to facilitate the extraction by eliminating the astringent off-flavors and anti-nutritional compounds, besides increasing the oil stability (Cisneros et al., 2014). We have not found documentation about the formation of trans-isomers in roasted seeds, but the presence of these compounds in the analyzed commercial oils could be indicative of a process where temperature is involved. In any case, the presence of steroidal hydrocarbons would confirm unmistakably presence of refined oil.

Finally, according to its FA composition (59.37\% Ln, $7.99 \%$ oleic, and $26.65 \%$ linoleic acids) sample number 14 could clearly belong to the P. huayllabambana ecotype.

As far as TG are concern, those with ECN 38 (LnLnL), 40, and 42 (formed by combinations of $\mathrm{Ln}, \mathrm{L}, \mathrm{O}$ and $\mathrm{P}$ ) are the main ones described for genuine sacha inchi oils in the limited publications that we have found on this subject (Fanali et al., 2014; Chasquibol et al., 2014). Also for genuine sacha inchi oils the TG with ECN 46 and 48 are present in percentages lower than $10 \%$, and the TG with ECN 50 (SSO) are present in percentages below $1 \%$. The most remarkable results are the TG with ECN 46 in the range 15.6-27.3 (Table 3) found in a few commercial oil samples $(3,5,6,7,9$ and 11). Also percentages of the TG with ECN 50 (3.0-5.1) higher than the $1 \%$ limit for authentic sacha inchi oils were found. The abnormal results belong to the same oils whose FA which do not match with a typical sacha inchi profile.

\subsection{Minor unsaponifiable compounds}

Sterols and tocopherols are the main components of the unsaponifiable matter present in the majority of the edible vegetable oils and they are known to display important health benefits. Their presence in sacha inchi oils is of great importance, qualitative and quantitatively speaking. Together with high amount of total sterols, sacha inchi oils have a particular sterol profile because, in contrast to other vegetable oils, the main sterol after $\beta$-sitosterol is stigmasterol instead of campesterol (Chasquibol et al., 2014). The calculation of the stigmasterol/campesterol ratio from data available in the literature regarding authentic sacha inchi oils, drove us to a ratio equal to 4 (2.7-7.0) (Bondioli et al., 2006; Castaño et al., 201; Chirimos et al., 


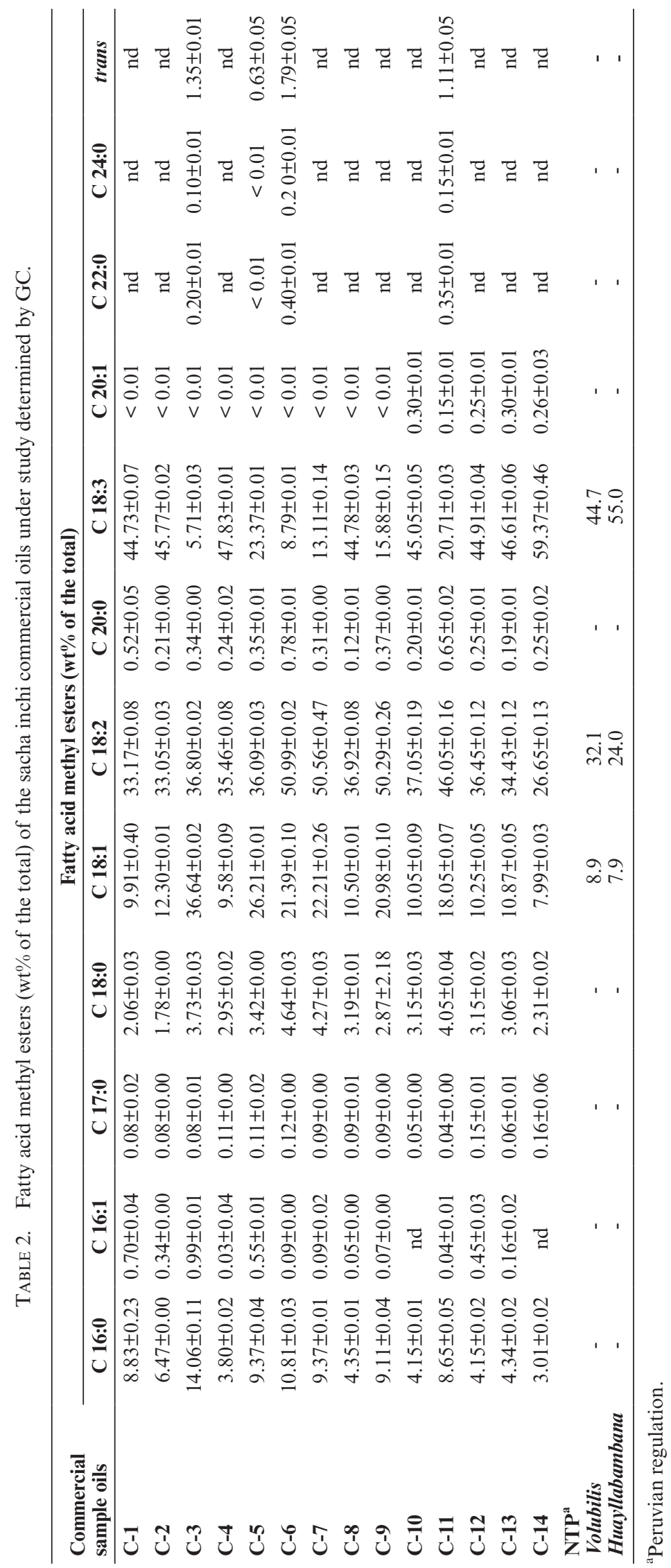


TABLE 3. Main tryglicerides grouped by their ECN determined by RP-HPLC-RI

\begin{tabular}{lrrrrrrrc}
\hline \multirow{2}{*}{$\begin{array}{l}\text { Commercial } \\
\text { sample oils }\end{array}$} & \multicolumn{1}{c}{ ECN36 } & \multicolumn{1}{c}{ ECN38 } & \multicolumn{1}{c}{ ECN40 } & ECN42 & ECN44 & \multicolumn{1}{c}{ ECN46 } & \multicolumn{1}{c}{ ECN48 } & ECN50 \\
\hline C-1 & $12.4 \pm 0.80$ & $22.2 \pm 1.14$ & $23.0 \pm 0.48$ & $22.0 \pm 0.98$ & $9.8 \pm 0.47$ & $4.9 \pm 0.21$ & $5.5 \pm 2.79$ & $0.7 \pm 0.29$ \\
C-2 & $17.7 \pm 0.40$ & $23.5 \pm 0.45$ & $18.7 \pm 0.41$ & $18.7 \pm 0.37$ & $8.6 \pm 0.14$ & $6.3 \pm 0.58$ & $5.9 \pm 0.62$ & $0.6 \pm 0.08$ \\
C-3 & $1.4 \pm 0.77$ & $2.8 \pm 0.20$ & $5.5 \pm 0.71$ & $13.5 \pm 0.52$ & $21.0 \pm 0.66$ & $27.3 \pm 0.49$ & $25.4 \pm 2.31$ & $3.1 \pm 0.16$ \\
C-4 & $12.3 \pm 0.11$ & $23.2 \pm 0.03$ & $25.1 \pm 0.07$ & $23.7 \pm 0.32$ & $11.0 \pm 0.16$ & $3.6 \pm 0.18$ & $0.8 \pm 0.02$ & $0.3 \pm 0.02$ \\
C-5 & $6.9 \pm 0.32$ & $13.3 \pm 0.58$ & $16.3 \pm 0.47$ & $19.5 \pm 0.54$ & $19.6 \pm 0.13$ & $15.8 \pm 0.62$ & $5.6 \pm 0.55$ & $3.0 \pm 0.98$ \\
C-6 & $1.4 \pm 0.01$ & $2.8 \pm 0.08$ & $8.0 \pm 0.21$ & $23.7 \pm 0.15$ & $27.1 \pm 0.53$ & $18.4 \pm 0.10$ & $13.5 \pm 1.33$ & $5.1 \pm 0.08$ \\
C-7 & $1.9 \pm 0.12$ & $4.8 \pm 0.23$ & $10.2 \pm 0.38$ & $23.6 \pm 0.51$ & $26.4 \pm 0.07$ & $17.3 \pm 0.57$ & $12.7 \pm 0.45$ & $3.1 \pm 0.21$ \\
C-8 & $10.4 \pm 0.13$ & $19.8 \pm 1.34$ & $23.1 \pm 1.24$ & $23.1 \pm 0.36$ & $13.3 \pm 0.33$ & $6.5 \pm 0.88$ & $3.1 \pm 1.19$ & $0.7 \pm 0.43$ \\
C-9 & $2.6 \pm 0.05$ & $6.5 \pm 0.14$ & $12.2 \pm 0.02$ & $24.9 \pm 0.30$ & $26.5 \pm 0.23$ & $16.3 \pm 0.19$ & $8.9 \pm 0.03$ & $2.1 \pm 0.18$ \\
C-10 & $11.1 \pm 0.05$ & $22.7 \pm 0.15$ & $24.4 \pm 0.16$ & $23.7 \pm 0.13$ & $11.9 \pm 0.10$ & $4.7 \pm 0.05$ & $1.0 \pm 0.01$ & $0.5 \pm$ \\
C-11 & $4.9 \pm 0.07$ & $9.6 \pm 0.08$ & $16.2 \pm 0.10$ & $27.1 \pm 0.15$ & $25.0 \pm 0.16$ & $15.6 \pm 0.10$ & $1.0 \pm 0.01$ & $0.6 \pm 0.05$ \\
C-12 & $10.2 \pm 0.06$ & $20.9 \pm 0.14$ & $25.6 \pm 0.15$ & $24.3 \pm 0.14$ & $12.3 \pm 0.12$ & $4.6 \pm 0.06$ & $1.3 \pm 0.01$ & $0.8 \pm 0.06$ \\
C-13 & $11.9 \pm 0.10$ & $21.9 \pm 0.16$ & $23.8 \pm 0.12$ & $23.9 \pm 0.14$ & $11.8 \pm 0.10$ & $4.6 \pm 0.06$ & $1.4 \pm 0.02$ & $0.7 \pm 0.08$ \\
C-14 & $10.9 \pm 0.11$ & $25.9 \pm 0.15$ & $23.7 \pm 0.14$ & $22.6 \pm 0.12$ & $11.4 \pm 0.11$ & $3.8 \pm 0.05$ & $1.5 \pm 0.02$ & $0.2 \pm 0.01$ \\
\hline
\end{tabular}

ECN (Equivalent carbon number).

2013; Chirimos et al., 2015). Studying the data on Table 4, we observe that C-3, C-5, C-6, C-7, C-9, and $\mathrm{C}-11$ samples are clearly out of this peculiarity. Besides, some samples of this group (C-5, C-6, C-7, C-9) show small percentages $(0.2-0.4 \%)$ of $\Delta-5$ stigmastadienol, an sterol which appears when the oil is subjected to refining.

Data presented in Table 5 show the high quantities of total tocopherols present in the studied samples. This parameter is included in the regulation where it is specified that sacha inchi oils must have at least $1900 \mathrm{mg} \cdot \mathrm{kg}^{-1}$ of total tocopherols. As one can observe, in spite of the high quantities, not all of the samples fulfill this requirement thus, C-3, C-5, C-6, C-7, C-9 and C-11 samples have lower values than required. Besides, usually sacha inchi oils have negligible quantities of $\alpha$-tocopherol and here the commercial oils (C-3, C-6, C7 and C-9) show quantities higher above $50 \mathrm{mg} \cdot \mathrm{kg}^{-1}$.

The C-8 sample fulfill the requirements: its total tocopherol concentration is $2013.6 \mathrm{mg} \cdot \mathrm{kg}^{-1}$, however two unknown peaks, not present in a normal tocopherol chromatogram, appear between the retention times corresponding to $\alpha$ - and $\beta$-tocopherols. We have approached the study of their structure by GC-MS using a mass spectrometer Polaris $Q$ (Thermo Finnigan, Manchester, UK) coupled to a gas chromatograph TRACE fitted with a DB-e MS.

For one of the peaks, the molecular ion $\left(\mathrm{M}^{+}\right)$was detected at m/z 354 and the base peak at m/z 149. For this compound the most important mass ion fragments are: 204, 203, 161, 150, 135 and 121 . The second peak has an $\mathrm{M}^{+}$to $\mathrm{m} / \mathrm{z} 370$ and a base peak 135 and its most important mass ion fragments are: 249 ,
233, 203, 150, 149 and 135 . To confirm the structures those compounds were analyzed by HPLC-MS-TOF, using a MICROTOF (Bruker Daltonic), allowing detect the exactly mass of both compounds being $377.0960(\mathrm{M}+\mathrm{Na})^{+}$and $393.0908(\mathrm{M}+\mathrm{Na})^{+}$. All the above results are consistent with the spectra described for sesamin and sesamolin. These two compounds are flavons present in sesame oils. Studying all the results corresponding to the C-8 sample we can observe that there is nothing that indicates that the oil has been diluted with sesame oil or with another kind of oil or fat because all its analytical parameters are within the regulation. Therefore, we believe that this sample has been contaminated with other kind of product in the same company or the oil was intended to be improved through an additive.

Hydrocarbons are the third group of compounds belonging to the most non-polar fraction of the unsaponifiable matter studied here. Lineal saturated hydrocarbons from 8 to 35 carbon atoms are compounds with demonstrated utility in oil characterization (Moreda et al., 2001). The H27:0, H29:0 and H31:0 odd elements are the most abundant in sunflower, safflower and sesame oils, whereas H23:0, $\mathrm{H} 25: 0, \mathrm{H} 27: 0$ and $\mathrm{H} 29: 0$ are detected in virgin olive oil. Our previous studies with genuine sacha inchi oils gave us a $\mathrm{HC}$ profile where the highest concentrations were obtained for $\mathrm{H} 23: 0$ and $\mathrm{H} 25: 0$, and those with even carbon-atom, mainly $\mathrm{H} 24: 0$, were also present.

The results presented in Table 6 show H23:0 as major HC (22-40\%), with two clear exceptions: C-3 and $\mathrm{C}-11$ samples, where $\mathrm{H} 27: 0$ is the major aliphatic saturated hydrocarbon, which indicates the presence of another seed oil. 

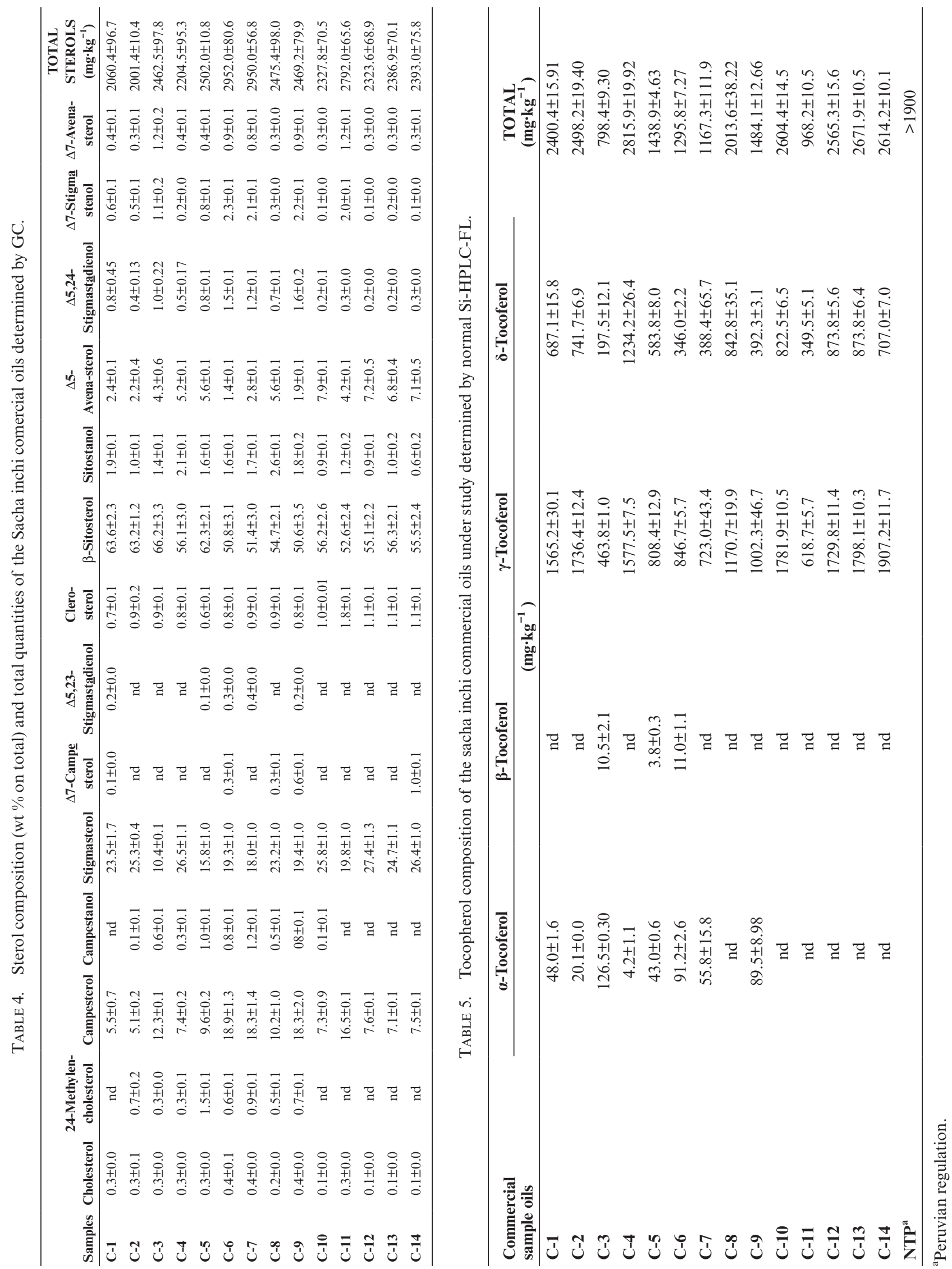

Grasas Aceites 67 (4), October-December 2016, e169. ISSN-L: 0017-3495 doi: http://dx.doi.org/10.3989/gya.0457161 
TABLE 6. Main aliphatic hydrocarbons of the sacha inchi commercial oils under study determined by on-column GC.

\begin{tabular}{|c|c|c|c|c|c|c|c|c|c|c|}
\hline \multirow{2}{*}{$\begin{array}{l}\text { Commercial } \\
\text { oil samples }\end{array}$} & \multicolumn{9}{|c|}{ ALIPHATIC HYDROCARBONS (wt $\%$ on total) } & \multirow{2}{*}{$\underset{\left(\mathrm{mg}^{\prime} \cdot \mathrm{kg}^{-1}\right)}{\text { TOTAL }}$} \\
\hline & H21:0 & H22:0 & H23:0 & H24:0 & H25:0 & H26:0 & H27:0 & H28:0 & H29:0 & \\
\hline $\mathrm{C}-1$ & $11.0 \pm 0.0$ & $10.9 \pm 0.9$ & $38.2 \pm 1.7$ & $18.2 \pm 0.9$ & $14.7 \pm 0.5$ & $2.0 \pm 0.1$ & $2.0 \pm 0.1$ & $1.5 \pm 0.1$ & $1.5 \pm 0.1$ & $114.6 \pm 1.7$ \\
\hline $\mathrm{C}-2$ & $11.1 \pm 0.0$ & $11.0 \pm 0.00$ & $39.1 \pm 1.6$ & $18.7 \pm 0.9$ & $14.9 \pm 0.8$ & $1.9 \pm 0.1$ & $1.4 \pm 0.2$ & $0.5 \pm 0.1$ & $1.4 \pm 0.1$ & $131.3 \pm 5.4$ \\
\hline $\mathrm{C}-3$ & $7.1 \pm 0.1$ & $6.9 \pm 0.7$ & $18.6 \pm 1.5$ & $10.5 \pm 0.8$ & $18.9 \pm 0.9$ & $10.5 \pm 0.1$ & $20.2 \pm 1.2$ & $6.2 \pm 0.1$ & $1.1 \pm 0.1$ & $21.7 \pm 0.3$ \\
\hline C-4 & $10.5 \pm 0.1$ & $13.8 \pm 0.9$ & $38.4 \pm 1.7$ & $22.4 \pm 0.9$ & $11.2 \pm 0.9$ & $0.4 \pm 0.1$ & $0.9 \pm 0.1$ & $1.3 \pm 0.1$ & $1.3 \pm 0.1$ & $92.7 \pm 7.1$ \\
\hline C-5 & $10.4 \pm 0.1$ & $13.3 \pm 0.9$ & $33.2 \pm 1.4$ & $19.5 \pm 0.9$ & $10.7 \pm 0.9$ & $2.1 \pm 0.1$ & $4.4 \pm 0.5$ & $4.7 \pm 0.1$ & $1.7 \pm 0.1$ & $34.8 \pm 1.1$ \\
\hline C-6 & $8.3 \pm 0.0$ & $9.8 \pm 0.9$ & $22.6 \pm 1.7$ & $18.4 \pm 0.7$ & $13.5 \pm 0.8$ & $11.5 \pm 0.6$ & $7.5 \pm 0.5$ & $7.3 \pm 0.1$ & $1.1 \pm 0.1$ & $12.3 \pm 0.7$ \\
\hline $\mathrm{C}-7$ & $10.6 \pm 0.0$ & $13.9 \pm 0.8$ & $29.8 \pm 1.5$ & $19.2 \pm 0.9$ & $9.7 \pm 0.9$ & $3.7 \pm 0.1$ & $5.9 \pm 0.5$ & $5.6 \pm 0.1$ & $1.5 \pm 0.1$ & $14.6 \pm 0.1$ \\
\hline $\mathrm{C}-8$ & $11.6 \pm 0.1$ & $14.0 \pm 0.9$ & $35.3 \pm 1.8$ & $20.1 \pm 1.0$ & $9.9 \pm 0.9$ & $2.5 \pm 0.1$ & $2.5 \pm 0.5$ & $3.0 \pm 0.2$ & $1.1 \pm 0.1$ & $60.6 \pm 6.7$ \\
\hline C-9 & $8.0 \pm 0.7$ & $12.4 \pm 0.9$ & $26.8 \pm 1.2$ & $17.2 \pm 0.9$ & $9.0 \pm 0.9$ & $5.8 \pm 0.4$ & $5.1 \pm 0.5$ & $14.6 \pm 0.6$ & $0.9 \pm 0.1$ & $22.3 \pm 1.3$ \\
\hline C-10 & $10.9 \pm 0.8$ & $12.8 \pm 0.9$ & $39.3 \pm 1.9$ & $21.3 \pm 0.9$ & $10.0 \pm 0.9$ & $0.8 \pm 0.1$ & $1.9 \pm 0.1$ & $1.7 \pm 0.1$ & $1.3 \pm 0.1$ & $100.5 \pm 1.5$ \\
\hline $\mathrm{C}-11$ & $8.1 \pm 0.7$ & $7.2 \pm 0.8$ & $18.0 \pm 1.7$ & $9.2 \pm 0.6$ & $19.1 \pm 0.9$ & $9.2 \pm 0.5$ & $21.0 \pm 1.1$ & $7.2 \pm 0.1$ & $1.0 \pm 0.1$ & $30.6 \pm 1.3$ \\
\hline C-12 & $10.3 \pm 0.9$ & $13.0 \pm 0.9$ & $38.8 \pm 1.7$ & $21.8 \pm 0.9$ & $12.2 \pm 0.8$ & $0.4 \pm 0.1$ & $0.9 \pm 0.1$ & $1.1 \pm 0.1$ & $1.5 \pm 0.1$ & $90.1 \pm 1.9$ \\
\hline C-13 & $11.0 \pm 0.8$ & $13.4 \pm 0.9$ & $39.5 \pm 1.8$ & $22.5 \pm 0.7$ & $10.3 \pm 0.1$ & $0.3 \pm 0.1$ & $0.8 \pm 0.0$ & $1.0 \pm 0.1$ & $1.2 \pm 0.1$ & $85.7 \pm 1.5$ \\
\hline C-14 & $11.6 \pm 0.9$ & $12.9 \pm 0.9$ & $40.5 \pm 1.5$ & $19.9 \pm 0.9$ & $10.6 \pm 0.1$ & $0.7 \pm 0.1$ & $1.1 \pm 0.1$ & $1.3 \pm 0.1$ & $1.4 \pm 0.1$ & $99.0 \pm 1.3$ \\
\hline
\end{tabular}

In relation to the steroideal hydrocarbons, they come from dehydration of the sterols during the different steps of the refining process, (Lanzón et al., 1994). Their formation during the heating process which take place when the seeds are roasted is also documented (Crew et al., 2006). In the present study no sterenes or steroideal hydrocarbons have been found. This fact guarantees the absence of refined oil in the commercialized samples under study.

\section{CONCLUSIONS}

The sacha inchi oils analyzed here include $P$. volubilis as the main ecotype commercialized, although the analytical parameters of one of the studied samples are clearly consistent with the analytical parameters required for P. huayllabambana. Probably as a consequence of their high unsaturation level, the oils are very susceptible to be degraded by hydrolysis and by oxidation thus, quality parameters such as the acidity value and the PV do not correspond to extra virgin oils as is specified in all the labels. All of the oils contain percentages of unsaponifiable matter much higher than the limit established in the regulation which, on the other hand, does not seem to be very consistent with having high content of valuable compounds as are sterols or tocopherols. The fatty acid composition alert us about the existence of six samples which clearly do not comply with the percentages required for $\omega-3, \omega-6$ and $\omega-9$ fatty acids or with the characteristic of having greater content of stigmasterol than campesterol presented in genuine oils. Although there is no presence of steroideal hydrocarbons, some of the samples, or more probably their seeds, may have been subjected to high temperature because trans isomers of fatty acids are present in quantities much higher than those expected for crude or virgin oils.

\section{ACKNOWLEDGEMENTS}

The financial support of Agencia Española de Cooperación Internacional para el Desarrollo (AECID) is gratefully acknowledge (Project AP/036672/11) and the Instituto de Investigación Científica (IDIC) de la Universidad de Lima-Perú (PI.56.006.2015). The authors would like to thank Mr. JL Rios for his assistance in the MS analysis.

\section{REFERENCES}

AOCS. Official methods of analysis. 2012. Method Ca 5a-40. Determination of free fatty acids. Official methods and recommended practices of the AOCS; American Oil Chemists' Society: Champaign, IL, USA.

AOCS. Official methods of analysis. 2013. Method Ja 8-87. Determination of peroxide value. Official methods and recommended practices of the AOCS; American Oil Chemists' Society: Champaign, IL, USA.

AOCS. Official methods of analysis. 1997. Method Cd 12b92. Sampling and analysis of commercial fats and oils: Oil stability index. Official methods and recommended practices of the AOCS; American Oil Chemists' Society: Champaign, IL, USA.

Bondioli P, Della Bella L, Rettke P. Alpha linolenic acid rich oils. 2006. Composition of Plukenetia volubilis (Sacha Inchi) oil from Peru. Riv. Ital. Sostanze Grasse 83, 120-123.

Bussmann R, Télllez C, Glenn A. 2009. Plukenetia huayllambambana (Euphorbiaceae) from upper Amazon of Perú. Nord. J. Bot. 27, 313-315. http://dx.doi. org/10.1111/j.1756-1051.2009.00460.x

Castaño DL, Valencia MP. 2012. Fatty acid composition of Inca peanut (Plukenetia volubilis L.) Rev. Chil. Nutr. 39, 45-52. 
Cert A, Moreda W, García-Moreno J. 1997. Determinación de esteroles y dialcoholes triterpénicos en aceite de oliva mediante separación de la fracción por cromatografía líquida de alta eficacia y análisis por cromatografía de gases. Estandarización del método analítico. Grasas Aceites 48, 207-218. http://dx.doi.org/10.3989/gya.1997.v48.i4.791

Cert A, Lanzón A, Carelli A, Albi T. 1994. Formation of stigmasta-3,5-diene in vegetable oils. Food Chem. 49, 287-293. http://dx.doi.org/10.1016/0308-8146(94)90173-2

Chasquibol N, Moreda W, Yaćono JC, Peŕez-Camino MC. 2012. Preliminary characterization studies on sacha inchi (Plukenetia volubilis L.) seeds and oils grown in San Martín, Perú. 20th International symposium on plant lipids (ISPL), Sevilla, Spain. p 167.

Chasquibol NA, del Aguila C, Yaćono JC, Guinda Á, Moreda W, Gómez-Coca RB, Peŕez-Camino MC. 2014. Characterization of Glyceridic and Unsaponifiable Compounds of Sacha Inchi (Plukenetia huayllabambana L.) Oils. J. Agric. Food Chem. 62, 10162-10169. http:// dx.doi.org/10.1021/jf5028697

Chirinos R, Zuloeta G, Pedreschi R, Mignolet E, Larondelle Y, Campos D. 2013. Sacha inchi (Plukenetia volubilis): A seed source of polyunsaturated fatty acid, tocopherols, phytosterols, phenolic compounds and antioxidant capacity. Food Chem. 171, 1732-1739. http://dx.doi.org/10.1016/j. foodchem.2013.04.078

Chirinos R, Pedreschi R, Domínguez G, Campos D. 2015. Comparison of the physic-chemical and phytochemical characteristics of the oil of two Plukenetia species. Food Chem. 173, 1203-1206. http://dx.doi.org/10.1016/j. foodchem.2014.10.120

Cisneros FH, Paredes D, Arana A, Cisneros-Zevallos L. 2014. Chemical composition, oxidative stability and antioxidant capacity of oil extracted from roasted seeds of sacha inchi (Plukenetia volubilis L). J. Agric. Food Chem. 62, 5191-5197. http://dx.doi.org/10.1021/jf500936j

Crews C, Hough P, Brereton P, Godward J, Lees M, Guiet S, Winkelmann W. 2006. Quantitation of the Main Constituents of Some Authentic Sesame Seed Oils of Different Origin. J. Agric. Food Chem. 54, 6266-6270. http://dx.doi.org/10.1021/jf0603578

Dobarganes MC, Cert A, Diffenbacher A. 1999. The determination of stigmastadienes in vegetable oils. Results of collaborative studies and the standardized method. Pure Appl. Chem. 71, 349-359. http://dx.doi.org/10.1351/ pac199971020349

Gómez-Coca RB, Pérez-Camino MC, Moreda W. 2015. Neutral lipids: Unsaponifiable matter. In Handbook of Food Analysis, 3rd ed., CRC Press. Taylor \& Francis Group: US, pp. 459-489.

Gómez-Coca RB, Cert R, Pérez-Camino MC, Moreda W. 2016. Determination of saturated aliphatic hydrocarbons in vegetable oils. Grasas Aceites 67, e127. http://dx.doi. org/10.3989/gya.0627152

Gutiérrez LF, Rosada LM, Jiménez A. 2011. Chemical composition of sacha inchi (Plukenetia volubilis L.) seeds and characteristics of their lipid fraction. Grasas Aceites 62, 76-83. http://dx.doi.org/10.3989/gya044510
International Standard Office, ISO 15788-2 (2003). Animal and vegetable fats and oils. Determination of stigmastadienes in vegetables oils.

IUPAC Standard Method 2.302. 1987a. Standard methods for the analysis of oils, fats and derivatives. Determination of FAMES by capillary GC. Blackwell Scientific: Oxford, Great Britain

IUPAC Standard Method 2.432. 1987b. Standard methods for the analysis of oils, fats and derivatives. Determination of tocopherol and tocotrienols in vegetable oils and fats by HPLC. Blackwell Scientific: Oxford, Great Britain.

IUPAC Standard Method 2.401. 1987. Standard methods for the analysis of oils, fats and derivatives. Determination of the unsaponifiable matter. Blackwell Scientific: Oxford, Great Britain

Lanzón A, Albi T, Cert A, Gracián J. 1994. The hydrocarbon fraction of virgin olive oil and changes resulting from refining. J. Am. Oil Chem. Soc. 71, 285-291. http://dx.doi. org/10.1007/BF02638054

Liua Q, Xua Y, Zhanga P, Naa Z, Tanga T, Shia Y. 2014 Chemical composition and oxidative evolution of Sacha Inchi (Pluketia volubilis L.) oil from Xishuangbanna (China). Grasas Aceites 65, e012. http://dx.doi.org/10.3989/ gya.075713

Maurer NE, Hatta-Sakoda B, Pascual-Chagman G, RodriguezSaona LE. 2012. Characterization and authentication of a novel vegetable source of omega-3 fatty acids, sacha inchi (Plukenetia volubilis L.) oil. Food Chem. 134, 1173-1180. http://dx.doi.org/10.1016/j.foodchem.2012.02.143

Moreda W, Pérez-Camino MC, Cert A. 2001. Gas and liquid chromatography of hydrocarbons in edible vegetable oils. J. Chromatogr. A. 936, 159-171. http://dx.doi.org/10.1016/ S0021-9673(01)01222-5

Moreda W, Pérez-Camino MC, Cert A. 2003. Improved method for the determination of triacylglycerols in olive oils by high performance liquid chromatography. Grasas Aceites 54, 175-179. http://dx.doi.org/10.3989/gya.2003.v54.i2.262

Muñoz Jauregui A, Alvarado-Ortíz C, Castañeda B, Lizaraso F, Barnett E, Caŕdenas L, Manco E. 2013. Estudio nutricional de Plukentia huayllabambana. Rev. Soc. Ouim. Perú 79, 47-56.

NTP. 2009. Norma Técnica Peruana151.400. Requisitos aceite sacha inchi, INDECOPI: Lima, Peru, 2010.

NTP. 2014. Norma Tećnica Peruana151.400, amendment to NTP 151.400, 2009. Requisitos Aceite Sacha Inchi, INDECOPI: Lima, Perú, 2014.

Ourrach I, Rada M, Pérez-Camino MC, Benaissa M, Guinda, A. 2012. Detection of argan oil adulterated with vegetable oils: new markers. Grasas Aceites 63, 355-364. http:// dx.doi.org/10.3989/gya.047212

Rodríguez A, Corazon-Guivin M, Cachique D, Mejia K, Del Castillo D, Renno J, García Dávila D. 2010. Diferenciación morfológica y por ISSR (inter simple sequencer epeats) de especies del género plukentia (Euphorbiaceae) de la amazonia peruana: Propuesta de una nueva especie. Rev. Peru. Biol. 17, 325-330.

UNE-EN 14111:2003. Fat and oil derivatives. Fatty Acid Methyl Esters (FAME). Determination of iodine value. 